\title{
Distribucija pomenov glagolskega predponskega obrazila po- $v$ češčini in ruščini
}

\author{
Žiga Mujakić
}

Prispevek analizira pomene glagolskega predponskega obrazila po- v češčini in ruščini na podlagi eskcerpcije dvojezičnega slovarja. Ob upoštevanju glagolskega vida in vrste glagolskega dejanja, kot ju pojmujejo češki in ruski jezikoslovci, se pomeni delijo na slovnične in slovnično-leksikalne, medtem ko so predpone praviloma polisemantične. Raziskava je potrdila, da se skupine pomenov v povezavi z vrstami glagolskega $\mathrm{v}$ obeh jezikih pretežno ujemajo. Največja razhajanja so pri glagolih premikanja s predpono po-, do razlik prihaja tudi v količinski distribuciji pomenskih skupin.

Ključne besede: ruščina, češčina, predpona, predponsko obrazilo, glagoli premikanja, vrsta glagolskega dejanja

\section{Distribution of meanings of the verbal prefix po- in Czech and Russian}

This paper analyzes the meanings of the verbal prefix po- in Czech and Russian based on excerpts from a bilingual dictionary. By taking into account verbal aspect and lexical aspect, as understood by Czech and Russian linguists, these meanings are divided into grammatical and grammatical-lexical meanings, whereas prefixes are generally polysemantic. The research confirmed that groups of meanings in combination with lexical aspect predominantly agree in both languages. The greatest divergence is in verbs of motion with the prefix $p o-$, and there are also differences in the quantitative distribution of semantic groups.

Key words: Russian, Czech, prefix, prefixal affix, verbs of motion, lexical aspect

\section{Glagolski vid in vrsta glagolskega dejanja}

$\mathrm{V}$ češčini in ruščini je prefiksacija, tako kot v vseh slovanskih jezikih, pomembno besedotvorno sredstvo, s katerim se tvorita glagolski vid in vrsta glagolskega dejanja. Čeprav gre za osrednji kategoriji slovanskega glagolskega ustroja, bi bilo zmotno domnevati, da o njiju med slavisti obstaja soglasje. ${ }^{1}$ Kot ugotavljata A. Zaliznjak in A. Šmeljov, se strinjanje o definiciji glagolskega vida konča pri ugotovi-

1 Slovnica Šahmatova in ruska akademska slovnica pišeta o vrstah glagolskega dejanja kot o »podvidih«. Isačenko razlikuje med vrsto glagolskega dejanja oziroma совершаемость (способ глагольного действия) in značajem glagolskega dejanja (характер глагольного действия) (рo Isačenko 1960: 215). 
tvi, da gre za slovnično kategorijo (Zaliznjak - Šmeljov 2000: 10). V primerjavi z glagolskim vidom pa vrsta glagolskega dejanja ni slovnična kategorija, saj njegovo izražanje v ruskem jeziku ni obvezno (Zaliznjak - Šmeljov 2000: 12). Vrsta glagolskega dejanja označuje različne tipe semantične modifikacije glagola, ki so izražene $\mathrm{s}$ formalnimi sredstvi (s predponskimi in priponskimi obrazili) in jo lahko razumemo kot pojmovno kategorijo vidskosti (tj. obstajanje situacije v času). Vendar se v primerjavi z vidom kategorija vrste glagolskega dejanja izraža z leksikalnimi sredstvi (Zaliznjak - Šmeljov 2000: 104). Vsak glagol je dovršnega ali nedovršnega vida, ${ }^{2}$ napačna raba glagolskega vida lahko povzroči neslovničnost povedi, medtem ko vrsta glagolskega dejanja le spreminja leksikalni pomen. Bondarko jo imenuje »podrazred« glagolske leksike, slovnično-leksikalno kategorijo, ki ne premore struktur, ki so značilne za morfološke kategorije (1976: 168).

\section{Tvorjenje glagolov $s$ prefigiranjem}

Predponske glagolske tvorjenke se besedotvorno uvrščajo med sestavljenke. ${ }^{3}$ Osnovna postopka pri glagolskih tvorjenkah sta prefigiranje in sufigiranje. Za tvorjenje sekundarnih nedovršnikov se uporabljata oba postopka. Na tem mestu nas zanimajo glagolske tvorjenke s predponskim obrazilom po-, ki je izmed vseh slovanskih predponskih obrazil eno najpogostejših s široko paleto pomenov. ${ }^{4}$ Prefigiranje je osnovni in najproduktivnejši način tvorjenja glagolov. V Češki slovnici beremo, da pomen predponskega glagola ni le navaden seštevek pomenov osnovnega glagola in predponskega obrazila, ${ }^{5}$ temveč je rezultat vzajemnega vplivanja teh pomenov (MČ 1986: 388). Pomen glagola pocvičit si (povaditi) izhaja iz udejanjanja pomena majhne mere, ki ga nosi predponsko obrazilo po-, in pomena osnovnega glagola, ki omogoča zamejitev v trajanju glagolskega dejanja. Nasprotno v zvezi покрасть вещи 'pokrasti stvari' predponski glagol ne izraža pomena majhne mere, ampak postopno odvijanje glagolskega dejanja.

S prefigiranjem se spreminja slovnični in včasih tudi leksikalni pomen glagola. Od tod razlikovanje med slovničnimi in leksikalnimi predponskimi obrazili, ${ }^{6}$ merilo za delitev predponskih obrazil na leksikalne in slovnične (semantično »prazne«) je možnost tvorjenja sekundarnih nedovršnikov (MČ 1986: 391). Isačenko

2 Dvovidski glagoli pri tem ne izstopajo. V odvisnosti od sobesedila prevzemajo dovršno ali nedovršno vidsko vlogo.

3 Ada Vidovič Muha uvršča predponske glagolske tvorjenke med sestavljenke, ki so skladenjsko s prvinami propozicije v pretvorbenem odnosu, znotraj katerega se prosti glagolski morfemi pretvarjajo v predponska obrazila (2009: 252).

4 Esvan navaja 933 dovršnih in sekundarnih nedovršnih tvorjenk s predponskim obrazilom po-, kar jih po frekvenci v korpusu SYN2000 uvršča na četrto mesto med vidskimi predponami v češkem jeziku (vy-: 1846, za-: 1761, z-: 1637, po-: 933) (Esvan 2007: 39).

5 V skladu s slovensko besedotvorno terminologijo uporabljamo termin predponsko obrazilo. Ob tem je treba opozoriti, da navedeni češki in ruski jezikoslovni viri razlikovanja med predpono in predponskim obrazilom ne uvajajo.

6 Vsako predponsko obrazilo je potencialno slovnično in leksikalno, pri nekaterih glagolih se spreminja le glagolski vid, pri drugih pa se leksikalno modificira glagolsko dejanje. 
pri tem opozarja, da lahko k vrsti vidskih parov tvorimo sekundarne nedovršnike, ki nimajo enakega pomena kot prvotni nedovršni glagoli (1960: 161). Omembe vredna je tudi polemika med Kopečnim in Poldaufom o obstoju »čisto vidskih«, »razvrstilnih « in leksikalnih predpon, ${ }^{7}$ ki posredno zadeva vprašanje definicije glagolskega vida in zlasti »slovničnosti« njegovega pomena. Ob upoštevanju teh razmišljanj obravnavamo prefigiranje $\mathrm{z}$ nastankom čistovidskega parnega glagola kot spremembo kategorialnega (slovničnega) pomena, ki se lahko izrazi tudi s pomenom rezultativnosti. Leksikalni pomen predponskega glagola pa razumemo kot pomensko modifikacijo glagola. Predponski glagol pridobi prislovni pomen, ki je neločljivo povezan s pomenom predponskega obrazila in se $\mathrm{z}$ drugimi sorodnimi predponskimi glagoli uvršča v vrsto glagolskega dejanja.

\section{Oris pomenov predponskega obrazila po- v češkem jezikoslovju}

Češka akademska slovnica kot najpogostejša pomena predponskega obrazila pov češčini omenja "pokriti površino nečesa (pomalovat, polepit, polit, posolit) in »(majhno) mero dejanja«: nekaj časa, malo (pohoupat, pobořit, pomačkat), omejitev intenzivnosti dejanja pri glagolih z dvodelnim predponskim obrazilom ( $p o-$ vzdechnout, povytáhnout, povyschnout), prekinjeno odvijanje dejanja in zmernejšo intenzivnost dejanja nedovršnega glagola (pobolivat, pokřikovat, poskakovat), daljše ali krajše trajanje s pomenom do zadostitve, dejanje, opravljeno z veseljem, do zadovoljstva (glagoli z refleksivnim si: postýskat si, požertovat si). ${ }^{8}$ Med preostalimi pomeni predponskega obrazila po- je navedeno še postopno odvijanje dejanja (večinoma pri predponskih nedovršnih glagolih: pozamykat, pozabijet, pochytat, postř́let), narediti nekaj takšno, kot označuje samostalniška osnova (pobratřit), pridobiti lastnost, ki jo označuje pridevniška osnova (potmavět, potemnět), dovršenost dejanja (pozdravit, postrašit, poradit, pochválit) ${ }^{9}$ (1985: 397-98).

7 Poldauf razlikuje med »čistovidskimi« in »razvrstilnimi« predponskimi obrazili(řadicí předpony). Pri obeh tipih gre le za spremembo glagolskega vida, le da se pri »razvrstilnih" predponski glagol vključuje v skupino skladenjsko in/ali semantično sorodnih glagolov (na-, pisati, slikati, risati itd.; na nekaj) in izraža »abstrakten pomen«, ki je skupen semom osnovnega glagola (1956: 170).

8 Priročna slovnica češčine (PSČ) tovrstnim glagolom pripisuje pomen vrednotenja dejanja, in sicer 'zadovoljstvo z dejanjem' (uspokojení z děje) (1995: 213).

9 V Slovenski slovnici so vrste glagolskega dejanja navedene v pregledu dovršnih in nedovršnih glagolov. Izmed nedovršnih glagolov s predponskim obrazilom po- so navedeni glagoli s pomenom malo: pošepavati, podrhtevati itd, ter trije glagoli s pomenom naknadnosti: pogrevati, požinjati, pokuhavati ... Pomen naknadnosti pri teh glagolih izhaja iz kombinacije spremljajočega pomena glagolov tipa pošepavati, in sicer 'od časa do časa, po malem', ter pomena osnovnega glagola. Vrste glagolskega dejanja pri dovršnih glagolih s predponskim obrazilom po- izražajo kratkotrajnost (poležati), dodatnost (pogreti), postajanje (pobledeti) (1984: 290). Glagolska predponska obrazila po pomenskih skupinah opisuje Milena Hajnšek-Holz (1978: 35) in glede na pomen jih deli na takšne s krajevnim, časovnim, načinovnim pomenom in dovršnostnim pomenom. Pri tem upošteva, da prihaja do prehodov med skupinami in združitev pomenov. 
Pomene pokritja površine nečesa (postopno zapolnjevanje površine), majhne mere glagolskega dejanja, prekinjenega odvijanja dejanja in postopnosti navaja že Kopečný v delu Glagolski vid v češčini (Kopečný 1962: 129-132). Novejša, Uhrova študija poleg omenjenih pomenov dodaja prostorski (poposednout, polit), eksistenčni (pochopit, porozumět, postřelit, pobit, pominout) in vrednotenjski pomen (posoudit, potlačit, povést, pomoct, potvrdit, pomluvit) (Uher 1986: 66-82). Pomen vrednotenja pozna tudi Priročna slovnica češčine, a ga pripisuje glagolom z refleksivnim si. Dodatno vpeljuje pomensko razlikovanje med nedoločeno in majhno mero glagolskega dejanja na podlagi formalnega merila enojne ali dvojne prefiksacije (pobavit, pocvičit, pochlubit se, pomazlit se : povyskočit, posmát se, pozeptat se, pozměnit) (PMČ 1995: 209).

\section{Oris pomenov predponskega obrazila po- v ruskem jezikoslovju}

Kot edina izmed glagolskih predpon ima predponsko obrazilo po- $\mathrm{v}$ češčini tudi prihodnjiški pomen. S tvorjenjem usmerjenih glagolov premikanja s predponskim obrazilom po- ne pride do čiste dovršnosti glagola niti do katere izmed leksikalnih modifikacij, ampak se na ta način tvori prihodnji čas (pưjdu - bom šel, pojdem; ponesu - bom nesel, ponesem; poletím - bom letel, poletim).

Pri ruskih avtorjih se je uveljavila precejšnja enotnost pri poimenovanju pomenov predponskega obrazila po- in njihovi vsebini. Tako Zaliznjakova in Avilova kot tudi akademska slovnica opozarjajo na poseben pomen predponskega obrazila po- pri glagolih usmerjenega premikanja (пойти, полететь). Tem glagolom pripisujejo pomen začetka glagolskega dejanja oz. ingresivni pomen. Tovrstni pomen imajo sicer še nekateri drugi glagoli, ki ne opisujejo premikanja (полюбить, почувствовать). Druge vrste glagolskega dejanja spominjajo na tiste v češčini: prekinjeno-atenuativna vrsta gl. d. (прерывисто-смягчительный способ гл. д.: noхаживать, посвистывать), distributivna (дистрибутивный способ гл. д.: noomкрывать, повыбивать), delimitativna (делимитативный способ гл. д.: пожить, погулять), atenuativna (атенуативний способ гл. д.: порассказать, позатемнеть), rezultativna (результативный способ гл. д.: построить).

\section{$5 \quad$ Polisemantičnost predponskega obrazila po-}

Iz navedenega izhaja, da so predponska obrazila polisemantična (Uher 1987: 23); konkreten pomen predponskega obrazila je odvisen od pomena osnovnega glagola in sobesedila. Češki glagol povykládat v povedi $S$ rovesniky si rád povykládal o politice ve světě ' $\mathrm{Z}$ vrstniki je rad malo poklepetal o politiki v svetu' pomeni nekaj časa, poved Stačila jim povykládat pohádky nebo přiběhy 'Uspela jim je povedati pravljice ali zgodbe' pa napeljuje na pomen »eno za drugo«. Enak pomen ima ruski glagol побороть v povedi Поборол всех противников 'Premagal je vse nasprotnike', medtem ko tega ne moremo reči za pomen iz sobesedila Я ещё с ними 
поборюсь, и ничего не сделают 'Še se bom z njimi (po)boril in ničesar ne bodo storili’ (Dostojevski), ki izkazuje pomen majhne mere glagolskega dejanja.

Zavedanje o polisemantičnosti glagolskega predponskega obrazila po- v češčini in ruščini porodi vprašanje, $v$ čem lahko najdemo skupno slovansko osnovo njenih slovničnih in leksikalnih pomenov ter katere so posebnosti rabe glagolov $\mathrm{s}$ predponskim obrazilom po- v obeh jezikih. V tem prispevku nas torej zanimajo količinske in kakovostne razlike $\mathrm{v}$ distribuciji pomenov predponskega obrazila po- $\mathrm{v}$ češkem in ruskem jeziku. Razlike v distribuciji vrst glagolskega dejanja in pomenov predponskega obrazila ${ }^{10}$ po- ugotavljamo na podlagi analize slovarskih pomenov ${ }^{11}$ čeških in ruskih glagolskih tvorjenk.

\section{Slovnični pomen predponskega obrazila po- $v$ češčini in ruščini}

6.1 Slovnični pomen predponskih obrazil izhaja iz spremembe glagolskega vida, pri čemer ne sme priti do kakršnih koli semantičnih modifikacij osnovnega glagola. Iz tega sledi, da prefigiranje s t. i. čistovidskimi predponskimi obrazili zadeva le slovnično kategorijo glagolskega vida, leksikalni pomen glagola pa ostaja enak. Nekateri jezikoslovci (Maslov, Isačenko) spremembo vida iz nedovršnega v dovršnega povezujejo s pomenom rezultativnosti, ki izraža dovršenost glagolskega dejanja do točke, ki pomeni dosego rezultata glagolskega dejanja. Isačenko ob tem opozarja, da se rezultativnost ne pokriva povsem z dovršnim vidom. V akademski slovnici lahko preberemo: »Vidski pari [...] se tvorijo le v primeru, da predponsko obrazilo glagolu ne prinaša dodatnega leksikalnega pomena (razen pomena meje, konca dejanja) (po Isačenko 1960: 157). V tem smislu pri dovršnih glagolih позавтракать, пообедать ni bistveno izražanje okoliščin glagolskega dejanja, ampak predvsem to, da je bilo dejanje dovršeno. Hkrati pa dejstvo, da obstaja več različnih predpon, s katerimi tvorimo dovršne glagole (dovršnost ima stalen pomen), napeljuje na ugotovitev, da je izbira predponskega obrazila odvisna od pomena osnovnega (nedovršnega) glagola. Takšen premislek pa nedvomno pritrjuje van Schooneveldovi tezi o redundanci pomena predponskega obrazila ${ }^{12}$ in osnovnega glagola.

${ }^{10}$ Raziskovanje pomenov glagolskih predponskih obrazil poteka $\mathrm{v}$ dveh smereh. Večina avtorjev (Avilova, A. Zaliznjak, Uher, Kopečný) si prizadeva za razmejitev in (p)opis pomenov predponskih obrazil, pri čemer Bogusławski (1960: 19) opozarja na nevarnost prevelike razdrobljenosti ali posplošitve pomenov. Iskanje semantične invariante predponskega obrazila predstavlja obraten pristop, Uher in Camus ga povezujeta s polisemantičnostjo predponskega obrazila (1987: 23). Težavo predstavlja predvsem visoka abstraktnost morebitnega invariantnega pomena, saj ga je empirično težko preveriti.

${ }^{11}$ Osnovo za izpis glagolskih tvorjenk s predpono po- sta predstavljala Češko-ruski (ČRS 1976) in Rusko-češki slovar iz leta 1976.

${ }^{12}$ Van Schooneveld meni, da je oznaka »prazna predpona« pri čistovidskih glagolih napačna. Po mnenju nizozemskega slavista ima predponsko obrazilo vedno nek abstrakten pomen. Ob tvorjenju glagolskih predponskih sestavljenk običajno pride do trka med pomenom osnovnega glagola in pomenom predponskega obrazila. Poudari se tisti pomen 
6.2 Dovršnih vidskih parov s predponskim obrazilo po-, ki označujejo dosego rezultata glagolskega dejanja, je $\mathrm{v}$ češčini manj kot $\mathrm{v}$ ruščini ${ }^{13}$ (146: 168). Mednje sodijo glagoli kot so: pozvat, potvrdit, potrestat, postarat se, pojmenovat, pochopit. Zelo pogosto se glagoli iz te skupine uvrščajo v več vrst glagolskega dejanja glede na sobesedilo: pochytil rybu / všechny ryby (ujel je ribo, vse ribe), krátce potloukl / potloukli se (kratko je potolkel, potolkli so se). Znotraj skupine vidskih parov težko najdemo omembe vredne skupne seme. Nekaj t. i. glagolov obedovanja se tvori s predponskim obrazilom po-: posvačit, pojist, posnidat, povečerét, poobědvat, še nekoliko številčnejša pa je skupina glagolov kot npr.: podařit se, pogratulovat, poděkovat, poblahoprát, povést se, poštěstit se, pochválit, polichotit, politovat, poctít, ki jih uvrščamo v pomensko skupino glagolov vrednotenja (podobno je storil v svoji razvrstitvi Uher, gl. točko 3).

6.3 V ruščini se med dovršne vidske pare uvrščajo glagoli kot npr.: позеленеть, покраснеть, пополнеть, позолотеть, пожениться, пожертвовать, пообещать, посереть, потеплеть, позвать, потонуть ... Ravno tako kot $\mathrm{v}$ češčini tudi v ruščini velja, da se dovršni glagoli obedovanja tvorijo s predponskim obrazilom po-: позавтракать, пообедать, поужинать.

Mnogi izmed teh glagolov se lahko sobesedilno uvrščajo tudi v druge vrste glagolskega dejanja. Težko bi našli skupno lastnost, ki bi povezovala vse te glagole, kar nekaj pa jih označuje spremembo barve (пожелтеть, посинеть, почернеть, порозоветь, поголубеть), spremembo telesnega stanja (потолстеть, потучнеть, похорошеть, постареть), spremembo temperature (похолодать, потеплеть, похолодеть, повлажнеть). Čeprav gre za rezultativno vrsto dejanja, je pri teh glagolih doseganje rezultata dejanja postopno, kar izhaja tudi iz pomena osnovnega glagola. Ker pomen postopnosti vsebuje predponsko obrazilo po-, nemara $\mathrm{v}$ tem tiči razlog, zakaj je za tvorjenje dovršnih glagolov v ruskem jeziku ravno predponsko obrazilo po- tako produktivno. Ti primeri lahko prispevajo $\mathrm{k}$ razumevanju polisemantičnosti predponskega obrazila po-, nikakor pa seveda z njimi ne moremo razložiti, zakaj se predponsko obrazilo po- uporablja za pare звать позвать, тонуть - потонуть ipd.

$\mathrm{Ob}$ primerjavi čeških in ruskih dovršnih rezultativnih glagolov ugotovimo precejšnje število ruskih predponskih glagolov s predponskim obrazilom po-, ki se $\mathrm{v}$ češčino prevajajo $\mathrm{s}$ predponskim obrazilom z-. Večinoma gre za glagole $\mathrm{s}$ postopnim doseganjem rezultata glagolskega dejanja, nekateri izmed njih označujejo spremembo barve oz. vidnih lastnosti predmeta ali osebe: побагроветь,

osnovnega glagola, ki sovpada s pomenom predpone, tako ob vzajemnem vplivanju predponskega obrazila in osnovnega glagola. Van Schooneveld imenuje tovrstno medsedbojno vplivanje semantična resonanca (van Schooneveld 1958: 161). Predponsko obrazilo je čistovidsko tedaj, ko določa naravni rezultat procesa, ki ga označuje leksikalni pomen glagola. Predponsko obrazilo se torej pomensko ujema z glagolom, zato van Schooneveld namesto o praznih predponah govori o semantični redundanci pomena.

${ }^{13}$ V SSJČ in PSČJ se za predponske glagole s po- navaja pomen posega na površini nečesa. Tega pomena ruski slovarji eksplicitno ne omenjajo, ampak tovrstne glagole beležijo kot vidske pare. 
позеленеть, порозоветь, посветлеть, посереть, посинеть, посмуглеть, посоловеть, пожелтеть, побелеть, поголубеть, покраснеть, помрачнеть, поржаветь, подурнеть, поблёкнуть ... ${ }^{14}$ Druga skupina glagolov označuje splošno spremembo lastnosti: погрубеть, потяжелеть, поумнеть, похорошеть, почерстветь, потолстеть, постареть, пополнеть, помертветь, потучнеть, посерьёзнеть, погрустнеть.

Seznam ruskih glagolov s predponskim obrazilom po-, ki se v češčino prevajajo s predponskim glagolom s predponskim obrazilom z-, je obsežen: побагроветь - znachovět 'zaripniti od jeze', ${ }^{15}$ позеленеть - zezelenat 'pozeleneti', порозоветь zrůžovět 'postati rožnat', посветлеть-zesvětlet 'posvetliti', nocepemь-zešednout 'posiveti', посинеть - zmodrat 'pomodreti', посмуглеть - zhnе̌dnout 'porjaveti', пожелтеть - zеžloutnout 'porumeneti', побелеть - zbělet 'pobeleti', поголубеть - zmodrat 'pomodreti', покраснеть - zrudnout 'pordečiti', помрачнеть - potemnět 'potemneti', поржаветь - žrezavět 'zarjaveti', nодурнеть - zošklivět 'postati grd', потяжелеть - ztěžknout 'postati težji', поумнеть - zmoudřet 'spametovati se', похорошеть - zkrásnět 'olepšati se', почерстветь - ztvrdnout 'otrdeti', потолстеть - ztloustnout 'zrediti se', nостареть - zestárnout 'postarati se, ostareti', nополнеть - ztloustnout 'zrediti se', помертветь (о глазах, о лице) -zmrtvět 'omedleti, odmreti', nотучнеть - ztloustnět 'zrediti se', nосерьёзнеть - zvážnět 'zresniti se', погрустнеть - zеsтитnе̌t 'razžalostiti', погасить (свет, лампу) zhasnout 'pogasniti, ugasniti', погубить - zkazit 'skvariti', nодремать - zdř́mnout si 'podremati', побеспокоиться - být znepokojen, znepokojovat se 'vznemiriti se', поздороветь - zotavit se, uzdravit se 'pozdraviti se', покритиковать - zkritizovat 'skritizirati', помереть - zетřit 'umreti', помёрзнуть (о деревьях) - роmrznout, zmrznout 'pomrzniti', помолчать - odmlčet se 'pomolčati, umolkniti', nопортить - pokazit, zkazit 'pokvariti', потерять (ключи) - ztratit 'izgubiti', nотухнуть (о костре, о лампе, о папиросе) - zhasnout 'ugasniti'.

Češki prehodni glagoli s pomenom 'narediti Y takšnega, kot je X' - poslovanštit (se), poruštit (se), pokřšstanštit (se), pokatoličtit (se), poevropštit in počeštit (se) - se v ruščino dosledno prevajajo z dvovidskimi glagoli словянизировать, русифицировать, христианизировать, европеизировать, чехизировать. ${ }^{16}$

${ }^{14}$ Če stanje v obeh jezikih primerjamo s slovenščino, ugotovimo, da se glagoli, ki označujejo spremembo barve, $v$ slovenščino dosledno prevajajo s predponskim obrazilom po(pozeleneti, posvetliti, posiveti, pomodreti, pobeliti, pordečiti, potemneti, porumeneti). Slovenščina ima pri tem več skupnih potez z ruščino kot s češčino. Pri drugi skupini glagolov, ki izražajo splošno spremembo lastnosti, pa je potrebno biti previden, saj se ti glagoli (v ruščini s predpono po-, v češčini s predpono z-) v slovenščino prevajajo zelo različno (postarati se, toda tudi ostareti, zresniti se, otrdeti, zrediti se, postati grd, spametovatise).

${ }^{15}$ Slovenski prevod je naveden le za tiste glagole, za katere lahko najdemo prevod v ruskoslovenskem ali češko-slovenskem slovarju. Razumljivo je, da je težko najti le en ustrezen prevod za posamezen glagol, zato so slovenski prevodi bolj kot ne ilustrativni.

${ }^{16}$ Slovenščina je nekje med češčino in ruščino, saj pozna poslovaniti, počeščiti, a tudi rusificirati, evropeizirati. 
7.1 V češčini obstaja nezanemarljiva skupina glagolov, katerim predponsko obrazilo po- pridaja pomen 'opraviti glagolsko dejanje po površini', pri čemer se glagolsko dejanja izvaja na celotni površini ali razpršeno, na nekaterih mestih. Poseg po površini nakazuje neke vrste distributivnost, ki pa ne zajema množinskosti udeležencev, ampak je omejena na samo glagolsko dejanje. Glagoli s tem pomenom dopuščajo različne sobesedilne interpretacije, bodisi v smislu majhne mere (posolit: malo), rezultativnosti (posolit: nanesti sol) ali razpršenosti glagolskega dejanja po površini (posolit: posoliti del površine).

Glagoli pochromovat (хромировать), pokovit (металлизировать), pobronzovat (бронзировать), ki nosijo pomen 'pokriti s tenko plastjo kovine', se v ruščino prevajajo z dvovidskim prevzetim glagolom. S predponskim obrazilom po-se v ruščino prevajata pozlatit (позолотить) in postř́břit (посеребрить). Glagoli, ki imajo v češčini pomen posega na površini se sicer v ruščino prevajajo precej različno, najpogosteje s predponskim obrazilom по-, včasih об- in ostalimi predponskimi obrazili: ${ }^{17}$ pozlatit (позолотить), pozinkovat (оцинковать), postř́břit (посеребрить), роchromovat (хромировать), росіпоvаt (полудить), pobronzovat (бронзировать), pokovit (металлизировать), povléct (покрыть), potřit (помазать), potáhnout (nокрыть), poškrábat (o/nou̧apanamb), posypat (nосыпnать), posolit (посолить), poprášit (nосыпать), ротоис̌it (обысыпать мукой), poтаzat (помазать), ротаstit (помазать жиром), pokmínovat (посыпать тмином), pohladit (погладить), pogumovat (прорезинить), рос́márat (исчертить), pocukrovat (nocaxapumb), poтосіit se (помочиться), polit se (облиться), pokapat se (закапаться), pokakat se (обкакаться), podélat se (обделаться), pос̌urat se (onисать), pocintat (se) (запашкать), pobryndat (se) (запачкать), poblit (se) (вырвать), poblinkat (срыгнуть), роzvracet (стошнить).

7.2 Pomen majhne oz. omejene mere predponsko obrazilo po- izraža z delimitativno vrsto glagolskega dejanja. Omejitev glagolskega dejanja v češčini in ruščini je lahko časovna (nekaj časa: pozdržet se, povařit, pomazlit se, poveselit se, povytáhnout, поездить, пожить ...), količinska (malo: pousmát se, pofoukat, povykládat, postřiknout, nогреть, пококетничать, подивиться ...) ali v nekaj primerih časovno-prostorska (do omejene višine in za kratek čas: povznést, povýšit; na mesto v bližini: pohnout, popojet, poodejít ...). Med temi slovarskimi pomeni obstajajo glede na sobesedilo številna prehajanja med vrstami glagolskega dejanja, razvejanost delimitativne vrste glagolskega dejanja v češčini pa napeljuje na misel, da gre

${ }^{17}$ Zanimivo je, da je pri tej skupini glagolov češčina zelo podobna slovenščini, ki za predponsko obrazilo po- ravno tako pozna pomen posega na površini nečesa. Ti češki glagoli se v slovenščino zelo dosledno prevajajo s predponskim obrazilom po-: pozlatiti, pocinkati, posrebriti, pocinkati, prevleči, popleskati/namazati, prevleči/povleči, popraskati, posipati, posoliti, potresti/poprašiti, pomokati, pomazati, namazati z maščobo, pogladiti, posladkati, politi se, pokapljati se, pokakati se, podelati se, polulati se, popackati. Pri nekaterih izmed njih se pomenu posega na površini pridružuje pomen majhne mere 'poprašiti, posladkati, posoliti'. 
za enega temeljnih pomenov predponskega obrazila po-. Izraz delimitativna vrsta glagolskega dejanja prevzemamo iz ruskega jezikoslovja (Avilova, A. Zaliznjak). Zdi se nam ustreznejši od poimenovanja majhna mera glagolskega dejanja, saj gre v resnici za različne (časovno, količinsko in prostorsko) omejitve glagolskega dejanja, čeprav velja, da je pomen količinske omejenosti v pregledanem gradivu najštevilčnejši.

Podrobnejši pregled glagolov, ki so v češčini in ruščini delimitativni, razkrije, da v tej skupini številni glagoli označujejo dejavnosti, ki sprožajo ugodje. $\mathrm{V}$ češčini imajo ti glagoli povratni zaimek $s i$ v dajalniku. Češka slovnica pomen glagolskega dejanja opisuje $\mathrm{z}$ besedami »do zadoščenja, opravljeno $\mathrm{z}$ veseljem, do zadovoljstva« (MČ 1985: 397), Priročna slovnica češčine pa jim pripisuje pomen »zadovoljstva z dejanjem« (PMČ 1995: 213). V ruščini se povratni zaimek v tem pomenu ne uporablja, pomensko kompleksnost teh glagolov je zato treba izraziti opisno: ${ }^{18}$ pocvičit - поупражняться, popovídat si - nоговорить, porozprávét si (pobesedovat si), побеседовать, povykládat si - позабавиться, posedět si nосидеть, popít si-nonumb, poležet si-nолежать, pospat si-nocnamb, pohrát si-nоиграть, poplavati si-nоплавать, pokoketovat si-nококетничать. Pri teh glagolih se zastavlja vprašanje, v kolikšni meri resnično lahko govorimo o majhni meri oz. časovni omejenosti glagolskega dejanja. Glede na opis iz Češke slovnice (MČ 1985) (do zadoščenja, z veseljem), v katerem gre vse prej kot za izražanje majhne mere glagolskega dejanja, bi bilo morda primerneje govoriti o deminutivnosti v glagolskem dejanju. Iz vsakdanje rabe jezika vemo, da izjave kot na primer: Greva poklepetat/se pozabavat/nekaj popit ipd. ne pomenijo nujno majhne mere. Da deminutivnost glagolskim tvorjenkam s predponskim obrazilom po- ni povsem tuja, nakazuje tudi poimenovanje deminutivno-iterativni način glagolskega dejanja za nedovršne glagole s predponskim obrazilom po- (tip pokašlávat-nокашливать).

$\mathrm{V}$ ruščini se za omejeno število glagolov (поразвлечься, пораздумать, пообсохнуть) s predponskim obrazilom po- $\mathrm{v}$ slovarjih pojavlja pomen blagega izvajanja glagolskega dejanja. A. Zaliznjak kot odločujočo značilnost navaja dvojno prefiksacijo, medtem ko delimitativni glagoli glagolsko dejanje zamejujejo količinsko, ga atenuativni kakovostno (Zaliznjak - Šmeljov 2000: 120). A. Derganc povzema, da gre predvsem za prostorečne in neknjižne glagole z dvodelnim predponskim obrazilom (1986: 15). ${ }^{19}$

7.3 V češčini in ruščini nekateri glagoli s predponskim obrazilom po- in množinskimi udeleženci izražajo postopnost glagolskega dejanja. Distributivna vrsta glagolskega dejanja A. Zaliznjak in Avilove, ki jo Kopečný imenuje postopnost glagolskega dejanja, Uher pa členjeno dejanje, je edina, ki je povsem odvisna

${ }^{18}$ Skoraj vsi v nadaljevanju našteti ruski in češki glagoli se tudi v slovenščino prevajajo $\mathrm{s}$ predponskim obrazilom po-: povaditi, poklepetati, pozabavati se, posedeti, popiti, poležati, pospati, poigrati se, poplavati. Enako kot ruščina tudi slovenščina v tem primeru ne uporablja povratnega zaimka.

${ }^{19}$ Stilistična zaznamovanost ruskih atenuativnih glagolov s predponskim obrazilom po- seveda vpliva tudi na to, da jih slovarji beležijo v zelo omejeni meri. 
od sobesedila: pozavirat (dveře), pozatýkat (zloděje), pozamykat (spisovatele), povraždit (neprítele), pokácet (stromy). Večinoma gre za nedovršne glagole, pri katerih se distributivnost ujema s procesualnostjo. Glagolsko dejanje postopno zajame vse udeležence, drugega za drugim in vse po vrsti: popadat - nonadamb 'popadati', pomrznout - помёрзнуть 'pomrzniti', popichat - поколоть 'popikati', pokrást, ukrást - покрасть 'pokrasti', pobrat - отнять 'pobrati', posbíra$t i$ - позабирать, пособирать 'zbirati, pobirati', poštípati - покусать 'popikati', postř́leti - перестрелять, порасстрелять 'postreliti', povražditi - поубивать 'pomoriti', pozamykati - nозапереть 'zapreti'.20 Distributivna vrsta glagolskega dejanja torej ni odvisna le od predponskega obrazila po- (ta distributivnostni pomen sicer semantično omogoča), temveč tudi od skladenjske vezave glagola (побороть страх, всех противников). Iz zapisanega lahko razberemo, da so zato prehajanja med vrstami glagolskega dejanja glede na število udeležencev razmeroma pogosta: Он поженился на ней. Сыновья уже все поженились.

7.4 Vpetost vrste glagolskega dejanja $v$ kategorijo glagolskega vida je očitna pri nekaterih nedovršnih glagolih s predponskim obrazilompo-: poblýskávat se поблёскивать 'svetlikati se', pobolivat - побаливать 'po malem boleti', pochichtávat se-nосмеиваться 'posmehovati se', pochrápávat-nохрапывать 'po malem smrčati', pohekávat - покряхтывать 'stokati', pohoupávat - покачивать 'pozibavati', pohoupávati se - покачиваться 'pozibavati', pohrávat si - поигрывать 'poigravati se', pokašlávat - покашливать 'pokašljevati', poklepávat, potukávat - постукивать 'potrkavati', pokrápávat - покрапьвать 'kapati', pokřikovat покрикивать 'vpiti', pokuřovat si - покуривать 'po malem kaditi', polehávat - полёжсивать 'poležavati', pomíchávat - помешивать 'po malem mešati', popichávat - покальвать 'po malem zbadati', popijet - попивать 'popivati', popiskávat - попискивать 'popiskavati', popískávat - посвыстивать 'požvižgavati', poplácávati - похлопьвать 'trepljati', popraskávat - потрескивать 'po malem prasketati', popohánèt - поторапливать 'priganjati', poskakat - повыскакивать 'poskakati', pospávati - nодрёмывать 'dremuckati', postávati - nостаивать 'postavati', postonávati - прихварывать 'bolehati', posupávat - nосапывать 'po malem sopihati', pošvihávat - постёгивать 'pošvrkovati', pošvihávati похлёстывать 'pošvrkovati', potřásat - потряхивать 'potresati', povyskakovat - повыскакивать 'poskakati iz'.

Navedenim glagolom je skupen pomen občasnega poteka glagolskega dejanja. Ta vrsta glagolskega dejanja je $\mathrm{v}$ ruščini bolj produktivna kot $\mathrm{v}$ češčini, poleg večjega števila primerov (med katerimi je nekaj stilno zaznamovanih) tudi formalno dosledno sledi zapisu по-koren-ы/a/ивать ( (Avilova, A. Zaliznjak) tovrstne glagole uvrščajo $\mathrm{v}$ deminutivno-iterativno vrsto glagolskega dejanja, ki izraža pomen od časa do časa (Zaliznjak - Šmeljov 2000:

${ }^{20} \mathrm{~V}$ slovenščini lahko za te glagole večinoma najdemo prevodni glagol s predponskim obrazilom po-, ki ima distributivni pomen, če je osebek ali predmet množinski, rezultativni pomen pa, če je edninski (pobrati vsa jabolka / pobrati jabolko). 
122), podobno Češka slovnica, ki piše o prekinjenem odvijanju dejanja in zmernejši intenzivnosti (MČ 1985: 397). Večinoma so ti glagoli s sufiksacijo izpeljani iz dovršnih glagolov, ki izražajo delimitativno vrsto glagolskega dejanja (покашлять, покурить, покричать, почрать), toda z njimi ne tvorijo vidskih parov. Glagoli deminutivno-iterativne vrste izražanje majhne mere ohranijo, dodaten pomen prekinjenega glagolskega dejanja pridobijo zaradi spremembe glagolskega vida.

\section{Glagoli premikanja s predponskim obrazilom po- v češčini in ruščini}

Leksikalno polje dovršnih glagolov premikanja s predponskim obrazilom po- si zasluži posebno obravnavo. Že Gebauer in pozneje Kopečný ugotavljata, da imajo ti glagoli v češčini prihodnjiški pomen: půjdu, pojedu, ponesu, povezu, polezu. Sem sodita tudi glagola porostu, pokvete, ki označujeta rast. ${ }^{21} \mathrm{~V}$ slovanskih jezikih vez med glagolskim časom in vidom slabi od severa proti jugu, Kopečný se dotakne tudi primerjave s slovenščino ${ }^{22}$ (1962: 46). Tudi v ruščini se dovršni glagoli premikanja s predponskim obrazilom po- uporabljajo za izražanje prihodnosti, za razliko od češčine pa izražajo tudi začetek glagolskega dejanja, ki po A. Zaliznjak te glagole uvršča v ingresivno vrsto glagolskega dejanja: noŭmu - jit, odejít 'iti, oditi', nоехать - jet, odjet 'iti, odpeljati se', nолететь - začit letět, poletět 'poletiti', nопльть - plavat, vyplout 'plavati, odplavati', полезть - začit lézt, polézt 'začeti lesti', понести - odnést, zanést 'ponesti, odnesti', побежать - rozběhnout se, dát se do běhu 'steči', nовеяmь - zavanout 'zapihati', nomauиmb - začít táhnout 'povleči, začeti vleči', nотянуть - potáhnout 'povleči, začeti vleči'. Poleg teh se k ingresivni vrsti glagolskega dejanja prišteva še nekaj drugih ruskih glagolov, ki ne označujejo nujno premikanja, npr.: покропить - začit pršet, rozpršet se 'začeti deževati', полить - začit lit, rozpršet se 'začeti deževati', полюбить - začit mít rád 'vzljubiti', посеять - nasit, zasit 'posejati, zasejati', поскакать - začít skákat 'začeti skakati', nocbinambcя - začit se sypat 'začeti sipati'. Češčina ingresivne vrste glagolskega dejanja pri glagolih s predpono po- ne pozna, ruski glagoli se zato najpogosteje prevajajo opisno ali z glagolskimi tvorjenkami s predponskimi obrazili roz- in za-, s katerima češčina izraža začetek glagolskega dejanja.

${ }^{21}$ Rast je pomensko ustrezna premikanju navzgor.

${ }^{22}$ Navaja vzporednice med slovenščino in češčino pri glagolih usmerjenega premikanja s predponskim obrazilom po-, ki imajo $\mathrm{v}$ češčini enoznačno funkcijo tvorjenja prihodnjika, medtem ko so v slovenščini oblike pojdem, poletim, popeljem se, ponesem ipd. po SSKJ danes stilistično zaznamovane, namesto njih se uporabljajo bom šel, bom (po)letel, se bom peljal, bom nesel. Še vedno torej velja, da obstaja v slovanskih jezikih vez med kategorijo glagolskega vida in glagolskega časa, ki se rahlja v smeri od slovanskega severa proti jugu. $\mathrm{V}$ češčini pri glagolih premikanja niti sobesedilno ni možen pomen majhne mere; v ta namen se uporablja dvodelno predponsko obrazilo popo- (poponesu, popojedu ...). 


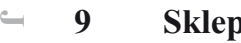

Iz zapisanega sledi, da glagolski vid nedvomno zamejuje vrsto glagolskega dejanja. Glagoli deminutivno-iterativne vrste glagolskega dejanja so namreč $\mathrm{v}$ obeh jezikih nedovršni, glagoli distributivne vrste glagolskega dejanja so v obeh jezikih pretežno nedovršni. Poleg tega lahko razliko med delimitativno in deminutivno-iterativno vrsto glagolskega dejanja pojasnimo le s spremembo glagolskega vida in sufiksacijo. Iz definicije glagolskega vida kot slovnično-leksikalne kategorije in vrste glagolskega dejanja kot leksikalne izhaja dvojnost slovnične in leksikalne vloge predponskega obrazila po-. Predponsko obrazilo po- se v češčini uporablja kot slovnični morfem pri glagolih premikanja za izražanje prihodnosti, pri drugih glagolih pa poleg spremembe vida označuje razne semantične modifikacije osnovnega glagola oz. vrste glagolskega dejanja.

Distribucija pomenov potrjuje polisemantičnost predponskega obrazila po-, predponski glagoli v obeh jezikih glede na pomen osnovnega glagola izražajo rezultativnost, pomene majhne mere, postopnosti in prekinjenega poteka. Pri vseh teh pomenih $\mathrm{v}$ češčini in ruščini opažamo količinske razlike: $\mathrm{v}$ ruščini je primerjalno nekoliko več glagolskih tvorjenk s predpono po-, ki se uvrščajo v delimitativno in deminutivno-atenuativno vrsto glagolskega dejanja. Poleg stičnih pomenov, v obeh jezikih opažamo tudi posebnosti: $v$ češčini upoštevamo pomen glagolskega dejanja na površju nečesa, $v$ ruščini pa ne moremo mimo pomena začetka dejanja pri nekaterih glagolih (predvsem) usmerjenega premikanja s predponskim obrazilom po-.

Skupni pomeni predponskega obrazila po- in odstopanja $\mathrm{v}$ obeh jezikih potrjujejo, da se pomeni predponskih obrazil in produktivnost tvorjenja $\mathrm{v}$ času spreminjajo. V pričujočem članku smo obravnavali večpomenskost predponskega obrazila po- na podlagi slovarskega gradiva, zato vanj niso vključeni novejši predponski glagoli domačega in tujega izvora, ki bi lahko nakazali, kako se produktivnost pomenov glagolskega predponskega obrazila po- razvija danes.

\section{Viri in literatura}

Avilova $1976=$ N. S. Avilova, Vid glagola i semantika glagol'nogo slova, Moskva: Nauka, 1976.

Boguslawski $1960=$ Andrzej Bogusławski, Prefiksalne pary aspektowe a semantyka prefiksalna czasownika rosyjskiego, Slavia Orientalis (Warszawa) 9 (1960), 139-175.

Bondarko 2005 = A. V. Bondarko, Teorija morfologičeskih kategorij $i$ aspektologičeskie issledovanija, Moskva: Jazyki russkoj kul'tury, 2005.

ČRS 1976 = L. V. Kopecký idr., Česko-ruský slovnik: P-Z̆, Praha: SPN, 1976.

Derganc 1986 = Aleksandra Derganc, Glagolska predpona po- $v$ ruščini in slovenščini, Vestnik Društva za tuje jezike in književnosti 20 (1986), št. 1-2, 12-21.

Esvan 2007 = François Esvan, Vidová morfologie českého slovesa, Praha: NLN Ústav Českého národního korpusu, 2007. 
Hajnšek Holz 1978 = Milena Hajnšek Holz, O pomenih slovenskih predpon, Seminar slovenskega jezika, literature in kulture: zbornik predavanj 14, Ljubljana: Filozofska fakulteta, Pedagoško-znanstvena enota za slovanske jezike in književnosti, 1978, 33-58.

Isačenko 1960 = Grammatičeskij stroj russkogo jazyka v sopostavljenii s slovackim 2: morfologija, Bratislava: Izdatel'stvo slovackoj akademii nauk, 1960.

Kopečný 1962 = František Kopečný, Slovesný vid v češtině, Praha: Nakladatelství ČSAV, 1962.

MČ 1986 = Mluvnice češtiny 1-2, Praha: Academia, 1986.

Poldauf 1956 = Ivan Poldauf, Ještě k »prostě vidovým předponám« v češtině, Slovo a slovesnost 15 (1956), 169-174.

PMČ 1995 = M. Grepl idr., Př́ruční mluvnice češtiny, Praha: NLN, 1995.

PSJČ 1935-1957 = Přiruční slovník jazyka českého 4/1, Praha: Státní nakladatelství, 1935-1957.

SS 1984 = Jože Toporišič, Slovenska slovnica, Maribor: Obzorja, ${ }^{2} 1984$.

SSJČ 1989 = Bohuslav Havránek (ur.), Slovník spisovného jazyka českého 4, Praha: Academia, 1989.

SSKJ = Slovar slovenskega knjižnega jezika 3: Ne-Pren, SAZU (izd.) - DZS (zal.), 1979.

Uher 1987 = František Uher, Slovesné předpony, Brno: Univerzita J. E. Purkyně, 1987.

van Schooneveld $1958=$ C. H. van Schooneveld, The so-called »préverbes vides « and neutralization, v: Dutch Contributions to the Fourth International Congress of Slavicists, s'Gravenhage: Mouton, 1958, 159-161.

Vidovič Muha 2009 = Ada Vidovič Muha, Skladenjska interpretacija glagolskih predponskih obrazil - vprašanje propozicije, Slavistična revija 57 (2009), št. 2, 251-261.

Zaliznjak - Šmeljov 2000 = A. A. Zaliznjak - A. D. Šmeljov, Vvedenie v russkuju aspektologiju, Moskva: Jazyki russkoj kul’tury, 2000. 
Žiga Mujakić, Distribucija pomenov glagolskega predponskega obrazila po- ...

\section{Distribution of meanings of the verbal prefix po- in Czech and Russian}

\section{Summary}

This paper contrastively examines the meanings of verbal prefix po- in Czech and Russian. The collected material is based on a collection of verbs with the prefix po- that were excerpted from a Czech-Russian bilingual dictionary. The data were classified by groups of meanings according to lexical aspect. Due to the polysemantic character of verbal prefix po-, some verbs could be classified into several groups that depend on contextual use. In Czech and Russian, verbs with the prefix po- bear grammatical and grammatical-lexical meanings. Grammatical meanings primarily include change of verbal aspect (from imperfective to perfective: pozvat, podékovat; пообедать, похолодеть). Russian perfective verbal pairs with the prefix po- to a great extent correspond with Czech perfective verbs with the prefix z- (посмуглеть - zhnе̌dnout, пожелтеть - zеžloutnout, nобелеть - zbělet). Prefixation with the prefix po- of verbs of motion implies different consequences in Czech and Russian. Russian determinate verbs of motion (nойти, nоexamь, полететь, попльть) bear ingressive lexical meaning expressing the start of the verbal act, whereas Czech verbs exercise a purely grammatical function of expressing the future (fut. puijdu, pojedu, poletim, ponesu). Some other lexical meanings are common to both languages regardless of terminological differences in this field: delimitative (росvicit si - поупражняться, ророvidat si-nоговорить, si pobesedovat si - nобеседовать), distributive (роštipati - nокусать, popadat nonaдать, ротrznout - помёрзнуть), and diminutive-iterative (poblýskávat se - поблёскивать, pobolivat - побаливать, pochichtávat se - посмеиваться). In addition to these groups of meanings, some verbs classified as pure verbal pairs in Russian (полудить, помазать, посолить) are seen as verbs in which the verbal act takes place on (top of) a substance (pokovit, pochromovat, posolit). However, the nature of the verbal act does not differ in either of the two languages. Therefore it can be concluded that, although different linguistic terminology is used, there are great resemblances in groups of meanings of the verbal prefix po- in Czech and Russian with the exception of determinate verbs of motion. 